\title{
Large prospective validation and cultural adaptation of the Polish version of the Swiss Spinal Stenosis Questionnaire for patients with lumbar spinal stenosis
}

\author{
Krzysztof Andrzej Tomaszewski ${ }^{1, A-F}$, Michał Kłosiński²,3,A-E, Brandon Michael Henry',A-E, \\ Bendik Skinningsrud ${ }^{3, A-E}$, Ewa Kucharska ${ }^{4, A-E}$, Zbigniew Dudkiewicz ${ }^{6, A-E}$, Robert Chrzanowski ${ }^{6, A-E}$, \\ Marcin Mikos, ${ }^{7,-E}$, Roman Głowacki ${ }^{8, A-E}$, Maria Pąchalska9,A-F \\ ${ }^{1}$ Health Outcomes Research Unit, Faculty of Education, Ignatianum Academy, Krakow, Poland \\ ${ }^{2}$ Department of Anatomy, Faculty of Medicine, Jagiellonian University Medical College, Krakow, Poland \\ ${ }^{3}$ Department of Orthopaedics, J. Dietl Specialistic Hospital, Krakow, Poland \\ ${ }^{4}$ Department of Gerontology, Geriatrics and Social Work, Faculty of Education, Ignatianum Academy, Krakow, Poland \\ ${ }^{5}$ Department of Orthopaedics and Hand Surgery, Medical University, Lodz, Poland \\ ${ }^{6}$ Faculty of Medicine, Andrzej Frycz Modrzewski University, Krakow, Poland \\ ${ }^{7}$ Ludwik Rydygier Specialistic Hospital, Krakow, Poland \\ ${ }^{8}$ Chair of Neuropsychology, Andrzej Frycz Modrzewski University, Krakow, Poland \\ ${ }^{9}$ Center for Cognition and Communication, New York, NY, USA \\ A - Research concept and design, B - Collection and/or assembly of data, C - Data analysis and interpretation, \\ $D$ - Writing the article, E-Critical revision of the article, F - Final approval of article
}

\begin{abstract}
Tomaszewski KA, Kłosiński M, Brandon MH, Skinningsrud B, Kucharska E, Dudkiewicz Z, Chrzanowski R, Mikos M, Głowacki R, Pąchalska M. Large prospective validation and cultural adaptation of the Polish version of the Swiss Spinal Stenosis Questionnaire for patients with lumbar spinal stenosis. Ann Agric Environ Med. 2017; 24(4): 676-682. doi: 10.26444/aaem/78674
\end{abstract}

\section{Abstract}

Objective. The aim of this prospective cohort study was to translate, validate and perform a cultural adaptation of the Polish version of the Swiss Spinal Stenosis Questionnaire (P-SSSQ), a disease-specific questionnaire for assessing symptom severity, physical function and satisfaction with treatment in patients with lumbar spinal stenosis (LSS).

Materials and method. Patients were prospectively recruited at two orthopedic centres in Krakow, Poland, between January 2011 - October 2016. During the interview, each patient completed the P-SSSQ, SF-36 Health Survey, and a demographic data questionnaire. After translation, cross-cultural adaptation, and pilot testing, assessment was made of the internal consistency, test-retest reliability, construct validity, and responsiveness of the P-SSSQ subscales.

Results. Finally, 171 consecutive patients were included in the study. Cronbach's alpha and ICC values were above 0.8 for all three subscales of the P-SSSQ. The symptom severity domain was highly negatively correlated with physical functioning and bodily pain of SF-36, with Pearson correlation coefficients of -0.68 and -0.63 , respectively. The physical function domain was highly negatively correlated with physical functioning $(r=-0.62)$. The satisfaction subscale was also highly negatively correlated with the change in the symptom severity $(r=-0.61)$ and physical function scale $(r=-0.65)$.

Conclusions. The proposed version of the P-SSSQ showed excellent measurement properties and can be considered validated for use in Polish. It is easy to understand, quick to complete, and the psychometric properties of the original version are maintained.

Key words

quality of life, lumbar spinal stenosis, Swiss Spinal Stenosis Questionnaire, Polish validation study

\section{INTRODUCTION}

Degenerating lumbar spinal stenosis (LSS) is a common disease in the elderly and consists in the narrowing of the vertebral canal and/or the intervertebral foramina due to degenerative changes in the facet joints, ligaments, vertebrae, and intervertebral discs, diminishing space for the neural and vascular elements in the central canal, causing compression of

Address for correspondence: Krzysztof Andrzej Tomaszewski, Health Outcomes Research Unit, Faculty of Education, Ignatianum Academy, Krakow, Poland e-mail: krtomaszewski@gmail.com

Received: 31.08.2017; accepted: 16.10.2017; first published: 10.11.2017 the nerve roots [1-3]. When symptomatic, patients complain of pain in the buttocks and lower extremities with low back pain, sometimes present due to intermittent neurogenic claudication, radicular pain, paresthesia, and weakness in the legs [3]. Generally, such symptoms worsen with walking and extended standing and improve with rest or forward bending [1]. Accordingly, people with LSS tend to avoid walking and have a reduced walking capacity. The effectiveness of conservative and operative treatments of patients with neurogenic claudication and LSS remains inconclusive. Uncertainty is compounded by methodologic variation in trials and the inconsistent use of outcome measures in the current published research [4-6]. 
There are several subjective evaluation studies that have produced outcome measures such as walking assessment and the intensity of low back pain during the course of the last 20 years, including the "Oswestry Disability Index," "Shuttle Walking Test," "Roland-Morris Disability Questionnaire," "Functional Rating Index," etc [3, 7]. However, none of them are spinal-stenosis specific. In addition, none of them can sufficiently assess symptoms other than pain, thus significantly limiting the possibility of a comprehensive assessment of LSS symptoms severity [8].

In recent years, the Swiss Spinal Stenosis Questionnaire (SSSQ) - also referred to as the "Swiss Spinal Stenosis measure," the "Zurich Claudication Questionnaire," and the "Brigham Spinal Stenosis Questionnaire" - has become a popular tool to measure adverse effects on walking capacity and the specific neuroischemic characteristics associated with degenerative lumbar spinal stenosis $[7,8]$. The SSSQ has been compared to three other similar outcome-measures: the "Shuttle walking test," the "Oxford Spinal Stenosis Score," and the "Oswestry Disability Index," in which the SSSQ was considered the most reproducible and spinal stenosis specific. ${ }^{2}$ Because of its disease-specific measurements, The North American Spine Society has declared the SSSQ as a potential "gold standard" in future studies investigating outcome measures in the treatment of LSS [7].

The SSSQ has been validated in several languages including English [9], Slovenian [10], Norwegian [11], German [1], and Chinese (simplified version) [3], but to-date a Polish version has not been validated. The aim of this prospective cohort study was to translate, validate and perform a cultural adaptation of the Swiss Spinal Stenosis Questionnaire on Polish (P-SSSQ) patients with lumbar spinal stenosis.

\section{MATERIALS AND METHOD}

Patients. The patients were prospectively recruited at two orthopedic centers in Krakow, Poland (The J. Dietl Specialist Hospital and The L. Rydygier Specialist Hospital) between January 2011 and October 2016.

Patients were eligible for inclusion if: 1) they were above 18 years of age, 2) had been qualified for spine surgery of the lumbar region due to either discopathy or non-traumatic spinal stenosis, 3) had uni- or bilateral neurogenic claudication (defined by pain in the buttocks and/or the lower extremities provoked by walking or extended standing and relieved by rest and/or bending forward), 4) had verified spinal stenosis (central or lateral verified by computer tomography or magnetic resonance imaging, 5) were able to give informed consent, 6) were available for a follow-up, and 7) were able to complete questionnaires in Polish. Exclusion criteria were: 1) an inability to understand or complete the questionnaires, 2) lack of consent to participate in the study, 3) red flags (e.g., cauda equine syndrome, infection, malignancy), 4) current vertebral fracture, 5) significant deformity (>15 deg lumbar scoliosis), and 6) clinically relevant peripheral arterial disease (confirmed by a vascular specialist) [1].

Clinical history and physical examination were registered from patient files for all the included patients. Either an MRI or CT of the lumbosacral region was performed, with the imaging method of choice being MRI. CT was only performed in the case of patients having metal implants preventing an MRI.
Interview procedure. Patients were approached and informed about the study one day before the surgery, and were interviewed only after written, informed consent was obtained. During the interview, each patient completed the Polish version of the SSSQ (P-SSSQ), SF-36, and a demographic data questionnaire. Qualified physicians administered all the questionnaires.

A subset of randomly chosen patients (based on a computer generated algorithm) completed the Polish version of the SSSQ twice for stability $(n=45)$ and responsiveness $(n=45)$ evaluation. Patients completing the Polish version of the SSSQ for stability were assessed at 14 days preoperatively and one day postoperatively, while patients completing the SF-36 for responsiveness were assessed one day preoperatively and 42 days postoperatively. All patients agreed to fill in the questionnaire a second time.

Questionnaires: SSSQ. The SSSQ (also known as the Spinal Stenosis Measure, Zurich Claudication Questionnaire, or Brigham Spinal Stenosis Questionnaire, Swiss Spinal Stenosis Questionnaire) measure is a disease-specific tool designed to complement generic measures of lumbar spine disability and health status in patients with lumbar spinal stenosis. It is a reproducible, valid, internally consistent, self-administered questionnaire validated in many languages [2, 9-11]. For academic purposes, the SSSQ is obtainable, from its' authors, free of charge and without the need of signing a specific license.

The SSSQ incorporates three subscales: 1) the SSSQ symptom severity scale (SSSQ symptom, 7 items), 2) the SSSQ physical function scale (SSSQ function, 5 items), and 3) the SSSQ satisfaction scale (6 items). The SSSQ symptom scale consists of a pain subdomain (3 items) and a neuroischemic subdomain (4 items). The symptom-severity scale is scored from 1-5, with higher scores denoting greater symptom severity, whereas the seventh item has only three possible responses corresponding to scores of 1,3 , or 5 . The functional disability and degree of satisfaction scales are each scored from 1-4, with higher scores representing greater disability or greater dissatisfaction, respectively. In each scale, the unweighted mean provides an overall score, provided that no more than two responses are missing [7].

The seven questions of symptom severity addressed overall pain, pain frequency, back pain, leg pain, numbness, weakness, and trunk balance, the six physical function questions asked about walking distance and the ability to walk for pleasure, for shopping, for getting around the house or apartment, and from bathroom to bedroom, and the six satisfaction questions asked about patient satisfaction with the overall results of the spinal surgery; pain relief after the surgery; walking ability after the surgery; the ability to do housework or yard work or a job after the surgery; strength in the thighs, legs, or feet; and balance or steadiness on one's feet [3].

SF-36. The SF-36 Health Survey is a brief, self-administered questionnaire composed of 36 questions and standardized response choices, organized into eight multi-item scales. The categories of health tested included physical functioning (PF), role limitations due to physical health problems (RP), bodily pain $(\mathrm{BP})$, general health perceptions $(\mathrm{GH})$, vitality (VT), social functioning (SF), role limitations due to emotional problems (RE), and general mental health $(\mathrm{MH})$ [12-14]. 
All raw scale scores are linearly converted to a 0 - 100 scale, with higher scores indicating higher levels of functioning or well-being. In this study, the pretranslated Polish version of the SF-36 by RAND was used [15]. This version is obtainable free of charge and without the need to sign a specific license agreement (https://www.rand.org/health/surveys_tools/ mos/36-item-short-form/terms.html). The main reason for choosing the SF-36 by RAND was the fact that this version is freely available for academic use, thus allowing for easy reproducibility of this study and also for designing and running potential follow-up trials.

Translation. The translation process of the original SSSQ to the P-SSSQ was completed according to Beaton et al. ${ }^{16}$ First, two independent forward translations were made (English $\rightarrow$ Polish) by two bilingual Polish native speaking orthopedic surgeons, one of them also a holder of the Cambridge Certificate of Proficiency in English. After comparing the translations, discrepancies were identified and reconciled by consensus with the help of a third reviewer (a professional English-Polish editor). This version was then translated backwards into English by two independent English native speakers with fluency in Polish, both expert translators, who were blinded to the study purpose. Both translators lacked medical backgrounds and were unaware of the prior translation procedures or the original document. The two obtained back translations were compared with the original English version of the SSSQ and checked for inconsistencies by the translation team. The team then consolidated the original questionnaire, translations, back translations, and corresponding written reports to reach a consensus $[17,18]$.

Pilot-testing, cross-cultural adaptation, and measures of SSSQ acceptability. Before finalizing the questionnaire, the P-SSSQ was pilot tested in 15 patients with lumbar spinal stenosis. Each patient completed the P-SSSQ and was subsequently interviewed as to whether he/she found any of the questions upsetting, confusing or difficult. The team discussed all the findings and then developed the final P-SSSQ which was subjected to further psychometric testing (Appendix 1) [19, 20].

The acceptability of the P-SSSQ was assessed by the response rate, percentage of missing data, assistance and time needed to complete the questionnaire and details of items considered upsetting, confusing or difficult in the questionnaire. Assessment of whether the patients found any of the P-SSSQ questions "upsetting, confusing or difficult" was carried out by asking the patients directly which (if any) of the P-SSSQ questions were upsetting, confusing or difficult. If a patient answered "yes" to any of the above, he was asked for additional comments on this subject $[20,21]$.

Statistical analysis. Several pre-planned standard psychometric tests were conducted, with the scoring of the two measures following the standard scoring instructions [1, 15]. To analyze the data, descriptive statistics (mean, standard deviation, percentage distribution) were used.

The unweighted mean was calculated for all subscales of all answered questions if fewer than two items were missing in the P-SSSQ function and P-SSSQ satisfaction, and fewer than three items were missing in the P-SSSQ symptom.
The significance level was set at $\mathrm{p}<0.05$. Statistical analysis was conducted using computer software Statistica 10.0 PL by StatSoft Poland (licensed to the Jagiellonian University Medical College in Krakow).

a) Statistical analysis - Validity. To confirm the hypothesized scale structure of the P-SSSQ, convergent and discriminant validity were used. Convergent validity was assessed by correlating each item with its own scale of the P-SSSQ [18, 22 ]. Evidence of item convergent validity was defined as a correlation of 0.40 or greater between an item and its own scale (corrected for overlap). Discriminant validity was assessed by correlating each item with any other scale of the P-SSSQ $[20,21]$. By "any other scale" the authors mean each of the P-SSSQ scales, apart from the scale from which the relevant item originates. A scaling success for an item was seen when the correlation between an item and its own scale (corrected for overlap) was significantly higher (i.e., two standard errors or greater) than its correlation with other scales [23].

Concurrent validity was evaluated by comparing P-SSSQ domains with the relevant domains of the SF36 questionnaire; correlation was made using Spearman correlation coefficients.

b) Statistical analysis - Reliability. Cronbach's alpha coefficient was calculated to assess the reliability of the P-SSSQ. Internal consistency estimates of a magnitude of $>0.70$ were considered acceptable for group comparisons [23].

Test-retest reliability of the P-SSSQ was assessed using interclass correlations (ICC) between baseline and retest in clinically stable patients. A correlation of $>0.80$ was considered "good".

c) Statistical analysis - Responsiveness to change over time. Assessment of responsiveness of the scales to treatment was conducted by comparing pre-treatment and post-treatment assessments of patients in which a clinically important difference was expected over the chosen period of time $(n=45)$. Due to the non-normality of the data the MannWhitney U test was used.

d) Statistical analysis - Sample size calculation. Study sample size was based on the proposal of Tabachnick and Fidell, which states that in order to obtain reliable estimates, the number of observations should be 5-10 times the number of variables in the model [24]. Thus, the required number of patients to conduct this study was between 90 to 180 .

Ethics. The protocol of this study was approved by the Jagiellonian University Medical College Bioethical Committee (Registry No. KBET/176/B/2011). Each patient gave their informed and written consent to participate in the study which was performed in accordance with the ethical standards laid down in the 1964 Declaration of Helsinki and its later amendments.

\section{RESULTS}

Patient characteristics and acceptability. During the 70 -month recruitment period a total of 241 patients were approached and 171 (71.0\% of approached patients) (92 women $-53.8 \%$ of included patients) agreed to take part in the study, with a mean age of $59.1 \pm 13.7$ years. Patients' 
demographic data are presented in Table 1. Overall, only $3.9 \%$ of item responses were missing.

Table 1. Patients' demographic data

\begin{tabular}{lc}
\hline Variable & Total $\mathrm{n}=171$ \\
\hline Age (mean \pm SD) & $59.1 \pm 13.7$ \\
\hline Female (\%) & $92(53.8 \%)$ \\
\hline Male (\%) & $79(46.2 \%)$ \\
\hline Education (\%) & $37(21.6)$ \\
\hline Elementary & $76(44.4)$ \\
\hline High School or equivalent & $58(33.9)$ \\
\hline University & $107(62.6)$ \\
\hline Current working status (\%) & $9(5.3)$ \\
\hline Employed (including on sick leave) & $55(32.2)$ \\
\hline Unemployed & $15(8.8)$ \\
\hline Retired/Pensioner & $146(85.4)$ \\
\hline Living (\%) & $10(5.8)$ \\
\hline Alone & $6.3 \pm 1.5$ \\
\hline With partner or family & $82(48.0)$ \\
\hline With others
\end{tabular}

Sixty-eight interviewees (39.8\%) required assistance completing the questionnaires. Help was required mostly in order to read the items and mark the answers. The total time for completion of the questionnaires and interview was $15.7 \pm 3.9$ minutes without assistance and $27.1 \pm 5.0$ with assistance.

No questions were considered upsetting, confusing or difficult, and as only minor language changes were suggested by individual patients, none of which were reported more than once, the final version of the P-SSSQ was approved, as was the final consensus translation used for pilot-testing.

Table 2 presents means, standard deviations, and percentage of floor and ceiling for P-SSSQ and SF-36 scales.

Validity and Reliability. The results of multi-trait scaling analyses of the P-SSSQ are presented in Table 3. The ownscale correlations of P-SSSQ were considered good, and all item correlations within their own scales exceeded the 0.40 criterion, and were correlated higher with their own scale than with the other scales. All presented Cronbach alpha values exceeded the 0.7 criterion.

For test-retest assessment, ICC was used. The ICC's for the P-SSSQ were 0.89 (95\%CI: 0.84-0.92) for the symptom severity scale, 0.91 (95\%CI: $0.87-0.93$ ) for the physical function scale, and 0.84 (95\%CI: $0.81-0.88)$ for the satisfaction scale - showing a good repeatability of the scales.

Concurrent validity was evaluated by comparing P-SSSQ domains with the relevant domains of the SF-36 questionnaire (Tab. 4).

Responsiveness to treatment (change of scores over time). Differences between pre-surgery and post-surgery assessments were evaluated for the scales of the P-SSSQ. Both scales of the P-SSSQ, that can be assessed pre- and post-surgery (the satisfaction scale can only be assessed post-surgery) displayed significant differences between the
Table 2. Means, standard deviations, and percentage of floor and ceiling for P-SSSQ and SF-36 scales

\begin{tabular}{llcc}
\hline \multirow{2}{*}{ P-SSSQ / SF-36 scales } & \multicolumn{3}{c}{ Whole group (n=171) } \\
\cline { 2 - 4 } & Mean (SD) & Floor (\%) & Ceiling (\%) \\
\hline P-SSSQ & $3.1(1.4)$ & 5.9 & 8.9 \\
\hline SS & $2.7(0.9)$ & 5.3 & 5.3 \\
\hline PhF & $3.3(1.1)$ & 6.4 & 5.3 \\
\hline Sat (post-surgery; at follow-up assessment) & & & \\
\hline SF-36 & $74.2(23.7)$ & 1.8 & 12.3 \\
\hline PF & $51.1(27.3)$ & 2.3 & 13.5 \\
\hline RP & $65.9(23.5)$ & 3.5 & 7.6 \\
\hline BP & $67.6(17.3)$ & 2.9 & 5.3 \\
\hline GH & $69.1(18.4)$ & 1.8 & 2.9 \\
\hline VT & $79.4(16.8)$ & 1.2 & 11.1 \\
\hline SF & $47.1(33.9)$ & 2.9 & 8.2 \\
\hline RE & $64.7(21.1)$ & 4.7 & 2.3 \\
\hline MH & & & \\
\hline SD - standard deviation; SS - symptom severity; PhF - physical function; & \\
Sat - satisfaction; PF - physical functioning; RP - role limitations due to physical \\
health problems; BP - bodily pain; GH - general health perceptions; \\
VT - vitality; SF - social functioning; RE - role limitations due to emotional problems; \\
MH - general mental health. & & & \\
\hline
\end{tabular}

Table 3. P-SSSQ multitrait scaling analyses

\begin{tabular}{|c|c|c|c|}
\hline \multirow{2}{*}{ P-SSSQ scales } & \multicolumn{3}{|c|}{ Whole group $(n=171)$} \\
\hline & Convergent validity ${ }^{\top}$ & Discriminant validity ${ }^{2}$ & Cronbach's alpha \\
\hline SS (7 items) & $0.57-0.72$ & $0.11-0.32$ & 0.90 \\
\hline PhF (5 items) & $0.51-0.68$ & $0.15-0.29$ & 0.87 \\
\hline Sat (6 items) & $0.45-0.58$ & $0.03-0.13$ & 0.84 \\
\hline
\end{tabular}

SS - symptom severity; PhF - physical function; Sat - satisfaction

${ }^{1}$ Item-own scale correlation, Spearman correlation coefficient, corrected for overlap ${ }^{2}$ Item-other scale correlation, absolute values displayed, Spearman correlation coefficient

Table 4. Concurrent validity of P-SSSQ scales with SF-36 scales

\begin{tabular}{cccccccccc}
\hline P-SSSQ & SF-36 & PF & RP & BP & GH & VT & SF & RE & MH \\
\hline SS & -0.65 & -0.68 & -0.36 & -0.63 & -0.44 & -0.55 & -0.48 & -0.35 & -0.30 \\
\hline PhF & -0.71 & -0.62 & -0.41 & -0.47 & -0.40 & -0.52 & -0.49 & -0.38 & -0.33
\end{tabular}

SS - symptom severity; PhF - physical function; PF - physical functioning; RP - role limitations due to physical health problems; $\mathrm{BP}$ - bodily pain; $\mathrm{GH}$ - general health perceptions; $\mathrm{VT}$ - vitality; $\mathrm{SF}$ - social functioning; $\mathrm{RE}$ - role limitations due to emotional problems; $\mathrm{MH}$ - general mental health;.

All correlations statistically significant at $\mathrm{p}<0.05$.

two assessments - symptom severity $(3.1 \pm 1.4$ vs $1.8 \pm 0.6$; $\mathrm{p}<0.0001)$, physical function $(2.7 \pm 0.9$ vs $1.4 \pm 0.8 ; \mathrm{p}<0.0001)$.

Satisfaction Scale of the P-SSSQ. This scale is assessed only post-operatively as it assesses patient satisfaction with the outcome of surgery. Forty-five patients from the initial group were selected to complete this assessment. All patients completed the follow-up assessment (26 males and 19 females; mean age of $58.4 \pm 10.9$ years). The Cronbach a value was 0.84 , whereas the ICC was 0.84 (95\% CI: 0.81-0.88).

The symptom severity scale score was $3.1 \pm 1.4$ before the surgery and $1.8 \pm 0.6$ after the surgery. The physical function scale score was $2.7 \pm 0.9$ before the surgery and $11.4 \pm 0.8$ after the surgery. The satisfaction scale score was highly negatively correlated with a change in the symptom severity $(\mathrm{r}=-0.61)$ and physical function scale $(\mathrm{r}=-0.65)$. 


\section{DISCUSSION}

In the last few decades, the number of surgeries for LSS has risen drastically and will no doubt continue to increase with the aging population. Measurement of walking capacity in LSS patients has proved to be an important asset in the assessment of physical function, treatment, diagnosis, and monitoring progression of the disease. As a result, there will be a growing demand for valid and reliable outcome-based measures of walking [8]. The SSSQ has been recognized as a useful tool to measure the specific neuroischemic characteristics and adverse effects on walking capacity associated with degenerative spinal stenosis, and has been used in several recent studies [10, 11, 25-27]. To the best of our knowledge, this study is the first to perform a large validation and cultural adaptation of the P-SSSQ for patients with LSS.

The presented study clearly shows that the P-SSSQ is a well-understood and reproducible tool to measure symptoms and disability in patients with LSS. It was appropriately translated, pilot-tested, and validated, regardless of language and cultural differences. The test results were reproducible, and the subscales showed a high internal consistency and good responsiveness. The P-SSSQ is simple and easy to use, and can be recommended in clinical and research practice in Polish patients.

The internal consistency, test-retest reliability, responsiveness, and methodology for the P-SSSQ were similar to other validation studies $[9,11]$. In the currentr study, the questionnaire was translated, back translated, modified, and predicted in accordance with the guidelines of Beaton et al [16]. The original questionnaire was translated and adapted on the basis of the different cultural backgrounds to help avoid mistaken interpretation and measurement [3]. The Cronbach a values of symptom severity and physical function domains were 0.90 and 0.87 , respectively, showing excellent internal consistency, in agreement with the values reported by Stucki et al. $(0.64,0.82)$ [9], Pratt et al. $(0.84,0.89)$ [2], and Thornes et al. $(0.96,0.94)[11]$. The ICCs of these two domains were 0.89 and 0.91 , respectively, which were the same as those reported by other authors: Stucki et al. $(0.94,0.94)$ [9], Pratt et al. $(0.82,0.93)$ [2], and Thornes et al. $(0.92,0.89)$ [11].

In the presented comparison of the P-SSSQ with the SF-36, the findings suggested that there was a significant negative correlation between them. In this study, the symptom severity domain was highly negatively correlated with the physical functioning and bodily pain of the SF-36, with Spearman correlation coefficients of -0.68 and -0.63 , respectively, whereas it was poorly correlated with $\mathrm{MH}(\mathrm{r}=-0.30)$. The low correlation coefficient with $\mathrm{MH}$ was due to the lack of psychology and sociology questions in the original SSSQ. The physical function domain was highly negatively correlated with physical functioning $(r=-0.62)$. These findings were comparable with the results of the original study.

With respect to the satisfaction domain, the Cronbach $\alpha$ and ICC of the P-SSSQ were both 0.84 , showing good repeatability and internal consistency. It was also highly negatively correlated with the change in the symptom severity $(r=-0.61)$ and physical function scale $(r=-0.65)$, in agreement with other studies [9]. This indicates that the scale of satisfaction can be more intuitive to reflect the operative outcomes, and a good reflection of the improvement in symptom severity and physical function after treatment.
There are some limitations to this study. Firstly, individuals under general practitioner care or who did not seek medical advice for their problem, were not included, and it is therefore likely that this analysis did not include individuals with milder symptoms and less disability. Second, only a limited number of tests were carried out for validation of the study. In the future, it may be necessary to perform other tests to establish stronger psychometric indexes for the P-SSSQ. In that case, using recognized clinical measures is recommended for known group comparison. Factor analysis might also help establish further psychometric evidence for the questionnaire [3]. Finally, no assessment of external validity of the SSSQ was undertaken in this study. Despite the above-mentioned limitations, we strictly followed current guidelines for the cross-cultural validation, complied with sample size requirements, and used recommended, conventional statistical methods to investigate the reliability of the P-SSSQ.

The P-SSSQ is an easy to use, well-understood selfreported questionnaire for assessing symptoms, function, and satisfaction in patients with LSS. The questionnaire can be used in research to assess these domains in patients with LSS. Reporting the subdomains of the P-SSSQ symptom scale separately is recommended, as this will allow clinicians and researchers to see the difference in the neuroischemic and pain symptoms. In particular, future researchers should aim to increase knowledge about the neuroischemic component in patients with LSS.

\section{CONCLUSIONS}

The English SSSQ was successfully translated into the P-SSSQ and culturally adapted for use on Polish patients with LSS. It is easy to understand, quick to complete, and the psychometric properties of the original version are maintained. The P-SSSQ is characterized by patient acceptability, reproducibility, as well as discriminative and construct validity. The authors suggest reporting the subdomains for pain and neuroischemic symptoms separately. The P-SSSQ can be widely used for assessing function in Polish LSS patients.

\section{REFERENCES}

1. Wertli MM, Steurer J, Wildi LM, Held U. Cross-cultural adaptation of the German version of the spinal stenosis measure. Eur Spine J. 2014; 23(6): 1309-19.

2. Pratt RK, Fairbank JCT, Virr A. The reliability of the Shuttle Walking Test, the Swiss Spinal Stenosis Questionnaire, the Oxford Spinal Stenosis Score, and the Oswestry Disability Index in the assessment of patients with lumbar spinal stenosis. Spine (Phila Pa 1976) 2002; 27(1): 84-91.

3. Yi H, Wei X, Zhang W, et al. Reliability and validity of simplified Chinese version of Swiss Spinal Stenosis Questionnaire for patients with degenerative lumbar spinal stenosis. Spine (Phila Pa 1976) 2014; 39(10): 820-5.

4. Deyo RA, Battie M, Beurskens AJ, et al. Outcome measures for low back pain research. A proposal for standardized use. Spine (Phila $\mathrm{Pa}$ 1976) 1998; 23(18): 2003-13.

5. Turner JA, Ersek M, Herron L, Deyo R. Surgery for lumbar spinal stenosis. Attempted meta-analysis of the literature. Spine (Phila Pa 1976) 1992; 17(1): $1-8$.

6. Siebert E, Prüss H, Klingebiel R, Failli V, Einhäupl KM, Schwab JM. Lumbar spinal stenosis: syndrome, diagnostics and treatment. Nat Rev Neurol. 2009; 5(7): 392-403.

7. Comer CM, Conaghan PG, Tennant A. Internal Construct Validity of the Swiss Spinal Stenosis Questionnaire. Spine (Phila Pa 1976) 2011; 36(23): 1969-76. 
8. Tomkins CC, Battié MC, Hu R. Construct Validity of the Physical Function Scale of the Swiss Spinal Stenosis Questionnaire for the Measurement of Walking Capacity. Spine (Phila Pa 1976) 2007; 32(17): $1896-901$.

9. Stucki G, Daltroy L, Liang MH, Lipson SJ, Fossel AH, Katz JN. Measurement properties of a self-administered outcome measure in lumbar spinal stenosis. Spine (Phila Pa 1976) 1996; 21(7): 796-803.

10. Fokter SK, Yerby SA. Patient-based outcomes for the operative treatment of degenerative lumbar spinal stenosis. Eur Spine J. 2006; 15(11): 1661-9.

11. Thornes E, Grotle M. Cross-cultural adaptation of the Norwegian version of the spinal stenosis measure. Eur Spine J. 2008; 17(3): 456-62.

12. Tomaszewski KA, Henry BM, Paradowski J, et al. Cross cultura adaptation of the English version of the IOF-QLQ to Polish, to assess the health-related quality-of-life of patients after a distal radius fracture. Health Qual Life Outcomes. 2015; 13(1): 158.

13. Kłosiński M, Tomaszewski KA, Tomaszewska IM, Kłosiński P, Skrzat J, Walocha JA. Validation of the Polish language version of the SF-36 Health Survey in patients suffering from lumbar spinal stenosis. Ann Agric Environ Med. 2014; 21(4): 866-70.

14. Henry BM, Wrażeń W, Hynnekleiv L, et al. Health-Related Qualityof-Life and Functional Outcomes in Short-Stem Versus Standard-Stem Total Hip Arthroplasty: An 18-Month Follow-Up Cohort Study. Med Sci Monit. 2016; 22: 4406-14.

15. Tylka J, Piotrowicz R. Quality of life questionnaire SF-36 -- Polish version. Kardiol Pol. 2009; 67(10): 1166-9.

16. Beaton DE, Bombardier C, Guillemin F, Ferraz MB. Guidelines for the process of cross-cultural adaptation of self-report measures. Spine (Phila Pa 1976) 2000; 25(24): 3186-91.

17. Chmielowska K, Tomaszewski KA, Pogrzebielski A, Brandberg Y, Romanowska-Dixon B. Translation and validation of the Polish version of the EORTC QLQ-OPT30 module for the assessment of health-related quality of life in patients with uveal melanoma. Eur J Cancer Care (Engl) 2013; 22(1): 88-96

18. Püsküllüoğlu M, Tomaszewski KA, Bottomley A, et al. Validation of the Polish version of the EORTC QLQ-BM22 module for the assessment of health-related quality of life in patients with bone metastases. Qual Life Res. 2014; 23(2): 527-32.

19. Püsküllüoğlu M, Tomaszewski KA, Zygulska AL, et al. Pilot Testing and Preliminary Psychometric Validation of the Polish Translation of the EORTC INFO25 Questionnaire: Validation of the Polish version of INFO25-pilot study. Appl Res Qual Life 2014; 9(3): 525-35.

20. Paradowska D, Bereza K, Sanna B, et al. A prospective study to validate the Polish language version of the European Organisation for Research and Treatment of Cancer (EORTC) Colorectal Liver Metastases (QLQLMC21) module. Eur J Oncol Nurs. 2017; 29: 148-54.

21. Sanna B, Bereza K, Paradowska D, et al. A large scale prospective clinical and psychometric validation of the EORTC colorectal (QLQCR29) module in Polish patients with colorectal cancer. Eur J Cancer Care (Engl) 2017; e12713.

22. Paradowska D, Tomaszewski KA, Bałajewicz-Nowak M, et al. Validation of the Polish version of the EORTC QLQ-CX24 module for the assessment of health-related quality of life in women with cervical cancer. Eur J Cancer Care (Engl) 2014; 23(2): 214-20.

23. Fayers P, Machin D. Quality of Life: The Assessment Analysis and Interpretation of Patient Reported Outcomes. Chichester: Wiley; 2007.

24. Tabachnick B, Fidell L. Using Multivariate Statistics. 4th ed. London: Harper Collins; 2011

25. Steurer J, Nydegger A, Held U, et al. LumbSten: The lumbar spinal stenosis outcome study. BMC Musculoskelet Disord. 2010; 11(1): 254

26. Ulrich NH, Kleinstück F, Woernle CM, et al. Clinical outcome in lumbar decompression surgery for spinal canal stenosis in the aged population: a prospective Swiss multicenter cohort study. Spine (Phila Pa 1976). 2015; 40(6): 415-22.

27. Ulrich NH, Burgstaller JM, Pichierri G, et al. Decompression Surgery Alone Versus Decompression Plus Fusion in Symptomatic Lumbar Spinal Stenosis: A Swiss Prospective Multicenter Cohort Study With 3 Years of Follow-up. Spine (Phila Pa 1976). 2017; 42(18): E1077-E1086.

28. Hidalgo Ovejero AM, Menéndez García M, Bermejo Fraile B, et al. Cross-cultural adaptation of the Zurich Claudication Questionnaire. Validation study of the Spanish version. An Sist Sanit Navar. 2015; 38(1): 41-52.

\section{Appendix 1. \\ Polish version of the Swiss Spinal Stenosis Questionnaire}

a) SSSQ symptom subscale:

W trakcie ostatniego miesiąca, jak by Pan/Pani opisał/a:

I. Średni ból jaki dolegał Panu/Pani, włączając w to ból pleców i pośladków, jak również ból promieniujący do nóg?

1. Brak

2. Lekki

3. Średni

4. Ciężki

5. Bardzo ciężki

II. Jak często miewał Pan/Pani ból pleców, pośladków lub nóg?

1. Rzadziej niż raz w tygodniu

2. Przynajmniej raz w tygodniu

3. Codziennie, przez przynajmniej kilka minut

4. Codziennie, przez większość dnia

5. Cały czas

\section{Ból Pana/Pani pleców lub pośladków?}

1. Brak

2. Lekki

3. Średni

4. Ciężki

5. Bardzo ciężki

\author{
IV. Ból Pana/Pani nóg lub stóp? \\ 1. Brak \\ 2. Lekki \\ 3. Średni \\ 4. Ciężki \\ 5. Bardzo ciężki
}

V. Niedoczulicę lub mrowienie w Pana/Pani nogach lub stopach?

1. Brak

2. Lekki

3. Średni

4. Ciężki

5. Bardzo ciężki

\section{Słabość w Pana/Pani nogach lub stopach?}

1. Brak

2. Lekki

3. Średni

4. Ciężki

5. Bardzo ciężki

VII. Pana/Pani problemy $\mathrm{z}$ równowagą?

1. Nie, nie miałem/am problemów $z$ równowagą

3. Tak, czasami czuję, że mam problemy z utrzymaniem równowagi lub nie jestem pewny/a, że stoję stabilnie na nogach 
5. Tak, często czuję, że mam problemy z utrzymaniem równowagi lub nie jestem pewny/a, że stoję stabilnie na nogach

\section{b) SSSQ function subscale:}

$\mathrm{W}$ trakcie ostatniego miesiąca, podczas przeciętnego dnia:

VIII. Jaki dystans był Pan/Pani w stanie przejśćc?

1. Więcej niż 3 kilometry

2. Więcej niż 400 metrów ale mniej niż 3 kilometry

3. Więcej niż 15 metrów ale mnie niż 3 kilometry

4. Mniej niż 15 metrów

IX. Czy dla przyjemności chodził/a Pan/Pani na spacery lub na zakupy?

1. Tak, bez dolegliwości

2. Tak, ale czasami odczuwałem/am ból

3. Tak, ale zawsze odczuwałem/am ból

4. Nie, nie chodziłem/chodziłam

X. Czy robił/a Pan/Pani zakupy spożywcze lub jakiekolwiek inne?

1. Tak, bez dolegliwości

2. Tak, ale czasami odczuwałem/am ból

3. Tak, ale zawsze odczuwałem/am ból

4. Nie, nie chodziłem/chodziłam

XI. Czy przechadzał/a się Pan/Pani po pokojach w swoim domu lub mieszkaniu?

1. Tak, bez dolegliwości

2. Tak, ale czasami odczuwałem/am ból

3. Tak, ale zawsze odczuwałem/am ból

4. Nie, nie chodziłem/chodziłam

XII. Czy chodził/a Pan/Pani ze swojej sypialni do lazienki?

1. Tak, bez dolegliwości

2. Tak, ale czasami odczuwałem/am ból

3. Tak, ale zawsze odczuwałem/am ból

4. Nie, nie chodziłem/chodziłam

\section{c) SSM satisfaction subscale:}

Jeśli w niedalekiej przeszłości przechodził/a Pan/ Pani leczenie operacyjne „pleców lub nóg”, to jak usatysfakcjonowany/a jest Pan/Pani z:

\section{Z ogólnego wyniku zabiegu operacyjnego?}

1. Bardzo zadowolony/a

2. Częściowo zadowolony/a

3. Częściowo niezadowolony/a

4. Bardzo niezadowolony/a

II. Ustąpienia bólu po zabiegu operacyjnym?

1. Bardzo zadowolony/a

2. Częściowo zadowolony/a

3. Częściowo niezadowolony/a

4. Bardzo niezadowolony/a

III. Możliwości chodzenia po zabiegu operacyjnym?

1. Bardzo zadowolony/a

2. Częściowo zadowolony/a

3. Częściowo niezadowolony/a

4. Bardzo niezadowolony/a

IV. Możliwości wykonywania prac domowych, prac ogrodowych lub pracy zawodowej po zabiegu operacyjnym?

1. Bardzo zadowolony/a

2. Częściowo zadowolony/a

3. Częściowo niezadowolony/a

4. Bardzo niezadowolony/a

V. Pana/Pani siły w udach, nogach i stopach?

1. Bardzo zadowolony/a

2. Częściowo zadowolony/a

3. Częściowo niezadowolony/a

4. Bardzo niezadowolony/a

VI. Pana/Pani równowagi i pewności podczas stania?

1. Bardzo zadowolony/a

2. Częściowo zadowolony/a

3. Częściowo niezadowolony/a

4. Bardzo niezadowolony/a 